\title{
Partial Analysis Of Tlx 1 And Tlx 3 Genes In Adult And Children Patients Of Acute T- Cell Lymphblastic Leukemia \\ S.S.Abdeen ${ }^{1}$, M.A.Ahmad ${ }^{2}$ and M.N.seddek ${ }^{1}$ \\ ${ }^{1}$ Immunology, Dept., Faculty of Science, Benha Univ., Benha, Egypt \\ ${ }^{2}$ Haematology, Dept., Faculty of Medicine, Benha Univ., Benha, Egypt \\ E-Mail:sarahsamir36@yahoo.com
}

\begin{abstract}
The genes TLX 1 and TLX 3 as two genes of the Hox gene family have been selected in this review. Such genes have been shown to have a certain function in malignancies, including acute lymphoblastic $\mathrm{T}$ cell leukaemia (T-ALL). The principal phases of the research involved extraction of DNA as well as gene sequence of normal and ill cases. This thesis included partial examination of the above two genes in T-cell Both patients for adults and infants. Further analyses were performed using bioinformatic tools to establish the variation in the secondary structure of mRNA. The key knowledge was obtained that the proposed protein products had physicochemical properties in relation to the secondary structure of mRNA. Finally, the variation in samples compared with standard controls will influence the stability of these protein products. This knowledge will serve both as a disease detector and in connection to patients with a relapse.
\end{abstract}

Key words: expression, genes, Egyptian, acute, lymphoplastic, leukemia, patients.

\section{Introduction}

Acute lymphoblastic leukaemia (Both), which is the most prevalent paediatric disease, accounts for about $20 \%$ of all adults, but $80 \%$ of children with leukaemia. The progress rate in the care of Both has gradually improved since the 1960s. The five-year event-free survival average for children with Both is about 80 per cent and for adults almost 40 per cent. [3]

Both subtypes have various therapy and prognostic responses, only slightly discriminated against by existing diagnostic methods, and genomic and gene expression profiling may further be determined. More precise delineation of genetic changes may also offer predictive statistics. The identification and quantification of minimum residual disease (MRD) proved essential in stratification of risk groups for both children and adults Both. [4]

HOX genes, a sub-group of homogeneous genes that regulate the body plan of an embryo along the headtail axis. HOX proteins are responsible for determining the type of appendages (e.g. legs, antennae and wings in fruchtflies) or the various forms of vertebrae (in humans) after the embryonic segments have formed. They also participate in the hemopoiesis control. Each HOX gene's protein product is a transcription factor. This includes a well-preserved DNA series called the homeobox. [5]

T-unit leukaemia TLX1 The homeobox1 gene (also referred to as TCL3 and HOX11) is a nuclear transcription factor that belongs to the homoobox subfamily NK-linked or NK-like (NKL). [18] This gene is situated on the 10th chromosome (Location 10q24.31). For normal spleen production during embryogenesis, the encoded protein is necessary. [19] This protein also has neuronal cell fate specifications. HOX11 may play an important role in leukemogenesis. There is some documentation. [20]

The constitutive expression of HOX11 has been especially shown to support the expansion and immortalization of murine hematopoietic progenitors in vitro. However, HOX11 has a higher forecast than other molecular T-ALL subtypes. [19]

The TLX3 T-cell leukaemia homeobox3 gene (also known as RNX and HOX11L2) is an orphan homeobox that covers a nuclear transcription factor which binds DNA. This gene is found on the 5th chromosome (Location: 5q35.1). T-cell acute lymphoblastic leukaemia (T-ALL) in children and young adults is correlated of a translocation with this gene (De Keersmaecker and Ferrando ,2011). Human T-cell leukemias can result from oncogenes caused by chromosome translocations of the T-cell receptor genes. Previous studies have shown that, in the absence of chromosome mutations based on their shared oncogenic pathways, five related $\mathrm{T}$ cell oncogenes (HOX11, TAL1, LMO1 and LMO2), are frequently aberrantly expressed and HOX11L2 activation established as a novel occurrence in T-cell leukemogenesis. These results are of therapeutic significance since the activation of HOX11 is strongly linked to a positive prognosis [10]

\section{Materials and Methods}

Whole blood samples were collected from the Specialized Pediatrics and University Hospitals of Benha. One of the normal samples is a female with 35 years old with no blood diseases history and the other is a 7 years old child with no blood diseases history. Two 
pediatric samples (one male and the other is female) each with 13 years old and diagnosed one and a half years before testing. Two male adult samples with 23 and 55 years old were collected just after diagnosed .

The extraction of DNA from blood samples of patients and control individuals was done using kit according to REF?.

Agarose gel electrophoresis was used to separate and purify DNA molecules

(Scitable, Nature Education, 2014)

Forward and reverse primers design was done by getting the sequence of genes going to be amplified from the GenBank (https://www.ncbi.nlm.nih.gov/genbank) and determining the coding region. Two primers must have annealing temperature value less than $65^{\circ} \mathrm{C}$. Primers were checked by the online bioinformatics site (http://www.bioinformatics.org)

Polymerase chain reaction (PCR) was carried out on TC96K gradient thermal cycler (Acculab, NY, USA). All reactions were performed in a volume of 50 $\mu$ PCR tubes, containing adequate amount of extracted template DNA, $2 \mu 1$ of each primer, $25 \mu$ l of master mix, $19 \mu 1$ of free nuclease water and $2 \mu$ of template DNA (15). Purification of PCR products was performed using QIAquick PCR Purification Kit (CA, USA).
Partial gene sequencing was carried out using the Applied Bio systems ${ }^{\circledR} \quad 3500$ and 3500xL Genetic Analyzers (HITACHI, 850 Lincoln Centre Drive, Foster City. California 94404, USA). Cycle Sequencing Purification Using Centri-Sep ${ }^{\mathrm{TM}}$ Kit (Princeton Separations, New Jersey, USA) was used.

After sequencing bioinformatics analysis was done. First, the NCBI blast tool was used to find the difference and similarities between control samples and their corresponding patients. In addition, the alignment of the predicted proteins from each sample was analyzed.

After that another alignment was done by T-coffe Multiple Sequence Server which is hosted by the Centre for Genomic Regulation (CRG, USA). This software was used also to get the predicted secondary shape for RNA. The positions and numbers of the stems and loops are found by the "Genebee" software (the bioinformatics portal of AN Belozersky Institute, supported by the Russian Foundation for Basic research, grant 13-0700969a, Moscow State University, Moscow, Russia).

\section{Results}

The study results are presented starting with the primers which have the following sequence depicted in Table 1 for the TLX1 gene and TLX3.

Table (1) The forward and reverse primers that were used in PCR.

\begin{tabular}{lcc}
\hline Gene name & Forward primer & Reverse primer \\
\hline Tlx1 & Cgccgtataa gtcacccta t & Ttgctcacctccactttgt \\
Tlx3 & Cggcatcgaccagatcetta & Cgggcacgcttattttcctg \\
\hline
\end{tabular}

Molecular characterization of TLX1 and TLX3 genes was done by three stages: DNA extraction, agarose gel electrophoresis and PCR amplification. Extracted DNA was examined for purity and it was confirmed by comparing the gels of all samples and controls Plate (1).
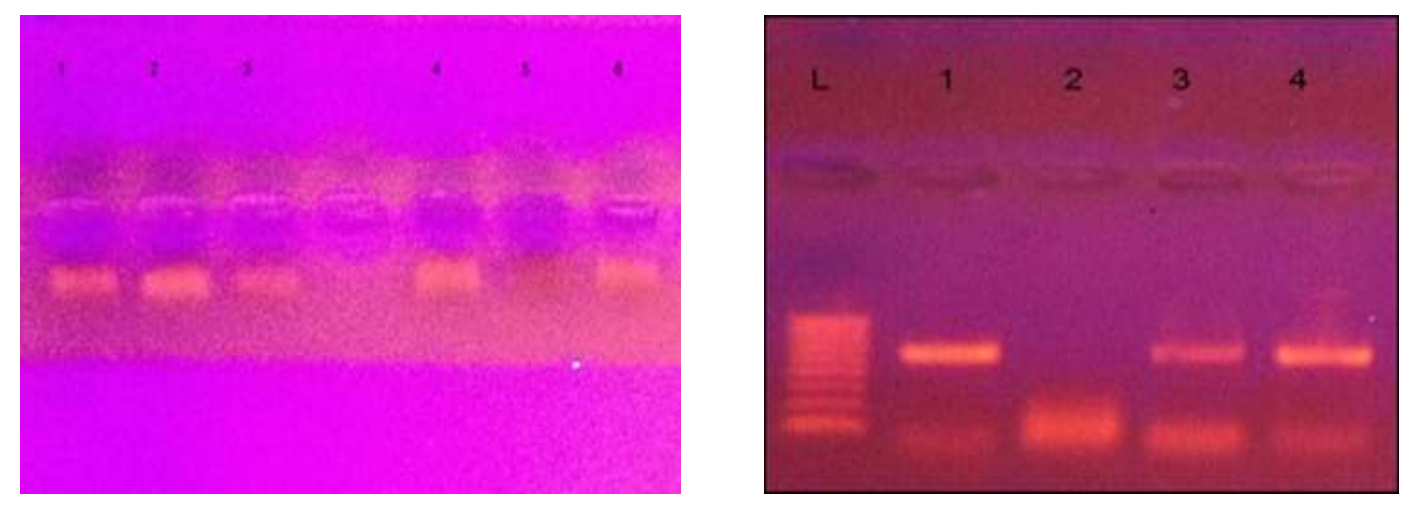

Plate (1) Southern blotting of DNA extracted from blood on the left and on the right is PCR product of samples on one of the genes as an example.

The gene sequencing charts were analyzed using NCBI GenBank and the difference are shown in the form of collective tables Table $(2,3)$. 
Table (2) Numbers of nucleotides and type of mutation found in samples of Gene TLX1.

\begin{tabular}{|c|c|c|c|c|}
\hline \multirow{2}{*}{ Sample } & \multirow{2}{*}{ Nucleotide number } & \multicolumn{3}{|c|}{ Type } \\
\hline & & Replacement & Missing & Addition \\
\hline \multirow[t]{3}{*}{ Adult .P. 1} & 8 & $\mathrm{G} \longrightarrow \mathrm{C}$ & & \\
\hline & 9 & & & G \\
\hline & 10 & & & $\mathrm{C}$ \\
\hline \multirow[t]{3}{*}{ Adult . P.2 } & 8 & $\mathrm{G} \longrightarrow \mathrm{C}$ & & \\
\hline & 9 & & & G \\
\hline & 10 & & & $\mathrm{C}$ \\
\hline \multirow[t]{17}{*}{ Ped . P.1 } & 3 & $\mathrm{G} \longrightarrow \mathrm{A}$ & & \\
\hline & 10 & $\mathrm{~A} \longrightarrow \mathrm{C}$ & & \\
\hline & 13 & $\mathrm{~T} \longrightarrow \mathrm{C}$ & & \\
\hline & 15 & $\mathrm{C} \longrightarrow \mathrm{T}$ & & \\
\hline & 21 & $\mathrm{~A} \longrightarrow \mathrm{G}$ & & \\
\hline & 23 & & G & \\
\hline & 27 & & G & \\
\hline & 32 & $\mathrm{C}$ & & \\
\hline & 33 & $\mathrm{C} \longrightarrow \mathrm{T}$ & & \\
\hline & 42 & & & G \\
\hline & 57 & & $\mathrm{C}$ & \\
\hline & 70 & & A & \\
\hline & 78 & $\mathrm{~T} \longrightarrow \mathrm{C}$ & & \\
\hline & 98 & & & $\mathrm{~T}$ \\
\hline & 132 & & $\mathrm{C}$ & \\
\hline & 140 & $\mathrm{G} \longrightarrow \mathrm{T}$ & & \\
\hline & 142 & $\mathrm{~T} \longrightarrow \mathrm{G}$ & & \\
\hline \multirow[t]{15}{*}{ Ped. P.2 } & 8 & $\mathrm{G} \longrightarrow \mathrm{C}$ & & \\
\hline & 10 & - $\mathrm{C}$ & & \\
\hline & 12 & & A & \\
\hline & 23 & & A & \\
\hline & 32 & & G & \\
\hline & 54 & $\mathrm{~T} \longrightarrow \mathrm{C}$ & & \\
\hline & 56 & $\mathrm{C} \longrightarrow \mathrm{A}$ & & \\
\hline & 58 & $\mathrm{~A} \rightarrow \mathrm{C}$ & & \\
\hline & 60 & $\mathrm{C} \longrightarrow \mathrm{A}$ & & \\
\hline & 64 & $\mathrm{~A} \longrightarrow \mathrm{G}$ & & \\
\hline & 149 & & $\mathrm{C}$ & \\
\hline & 153 & $\mathrm{C} \longrightarrow \mathrm{T}$ & & \\
\hline & 155 & & G & \\
\hline & 156 & & A & \\
\hline & 157 & $\mathrm{C} \longrightarrow \mathrm{A}$ & & \\
\hline
\end{tabular}

Table (3) Numbers of nucleotide and type of mutation found in samples of Gene TLX3.

\begin{tabular}{rcccc}
\hline Sample & Nucleotide number & & TyPe & \\
\cline { 2 - 5 } & & Replacement & Missing & Addition \\
\hline Adult .P. 1 & 3 & $\mathrm{C} \longrightarrow \mathrm{G}$ & $\mathrm{C}$ & \\
& 14 & & & $\mathrm{C}$ \\
& 21 & & $\mathrm{C}$ \\
& 22 & & $\mathrm{C}$ \\
Adult .P.2 & 25 & $\mathrm{C} \longrightarrow \mathrm{G}$ & & \\
& 3 & $\mathrm{C} \longrightarrow \mathrm{G}$ & $\mathrm{C}$ & \\
Ped. P.1 & 57 & & & $\mathrm{C}$ \\
Ped.P.2 & 58 & & & $\mathrm{~T}$ \\
\hline
\end{tabular}




\begin{tabular}{lll}
\hline 12 & $\mathrm{C} \longrightarrow \mathrm{C}$ & \\
13 & $\mathrm{C} \longrightarrow \mathrm{G}$ & \\
22 & $\mathrm{C} \longrightarrow \mathrm{T}$ & \\
24 & $\mathrm{C} \longrightarrow \mathrm{C}$ & \\
34 & $\mathrm{G} \longrightarrow \mathrm{C}$ & \\
35 & $\mathrm{C} \longrightarrow \mathrm{T}$ & \\
36 & $\mathrm{C} \longrightarrow \mathrm{T}$ & \\
50 & $\mathrm{C} \longrightarrow \mathrm{T}$ & \\
51 & & $\mathrm{~T}$ \\
52 & & $\mathrm{~T}$ \\
89 & & $\mathrm{~T}$ \\
90 & & \\
91 & & \\
\hline
\end{tabular}
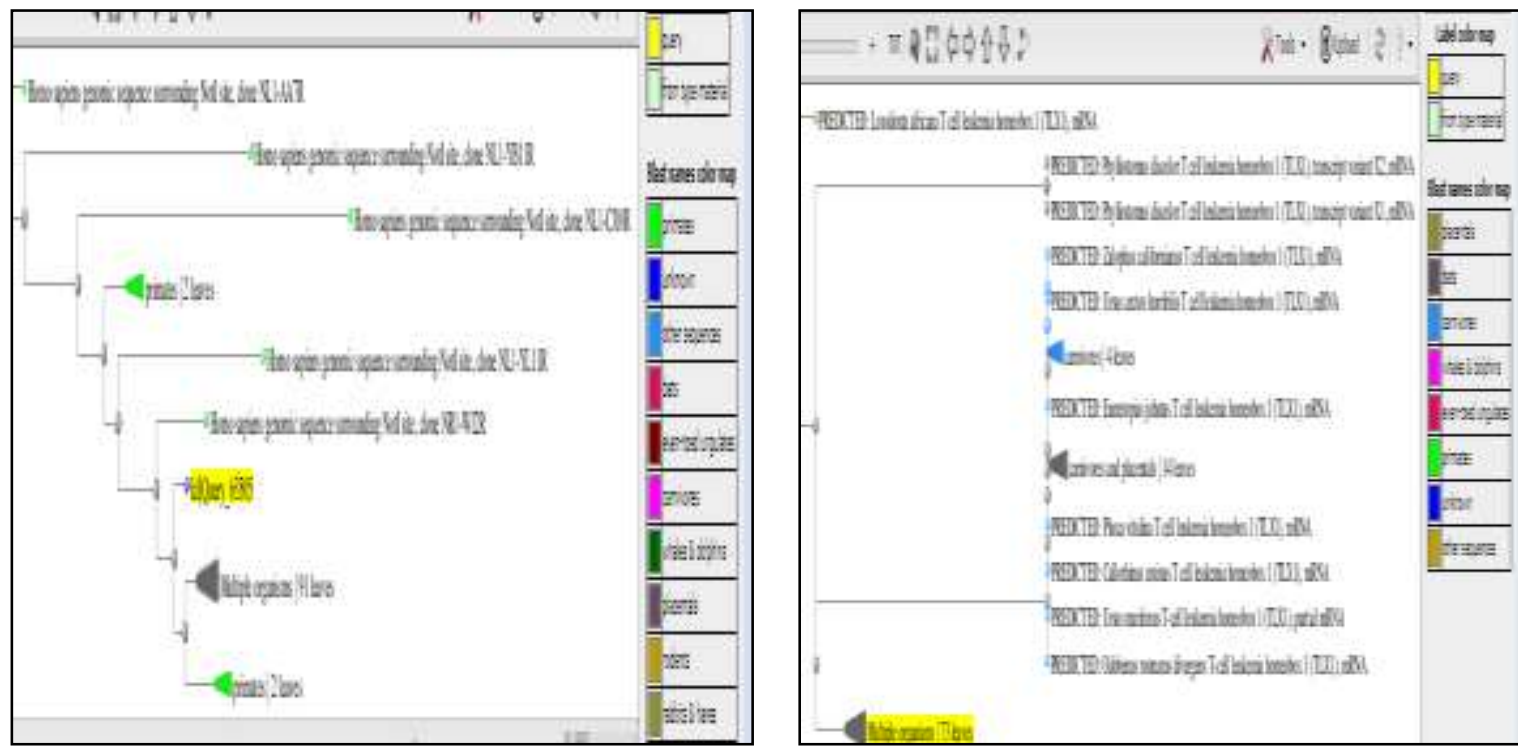

Plate (2) phylogenic analyses of TLX1 gene and TLX3 gene in Homo sapiens and other organisms, the scale for the branch length ( 0.75 substitutions per site).

The phylogenic correlation of each of the two genes was done using the NCBI facility online. The results are included in plate (2).

phylogenic analyses of TLX1 gene in Homo sapiens and other organisms showing nearest similarities with placental and outmost similarities with carnivores and for Tlx3 gene in Homo sapiens and other organisms showing nearest similarities with primates

The secondry structure or possible mRNA was analysed using Genebee software. Positions and number of loops (plate3) the numbers of the stems and heads of the secondry structure of RNA of the gene TLX1, the three samples (adult/children) were analysed, control sample has 12 stems but both patients have 9 stems. The first five stems doesn't have difference in free energy (difference was only in positions and sequences) but the rest stems have differences in all aspects. Both patients have similar results but differ with the normal.For the gene TLX3 the numbers of the stems and heads of the secondry structure of RNA the three samples (children control and 2 patients) were analysed and data are schedualed, control sample has 22 stems patient 1 has 24 also pateint 2 has 23.all the stems have differences in the sequences and posiotion of stems and somehow free energys . 

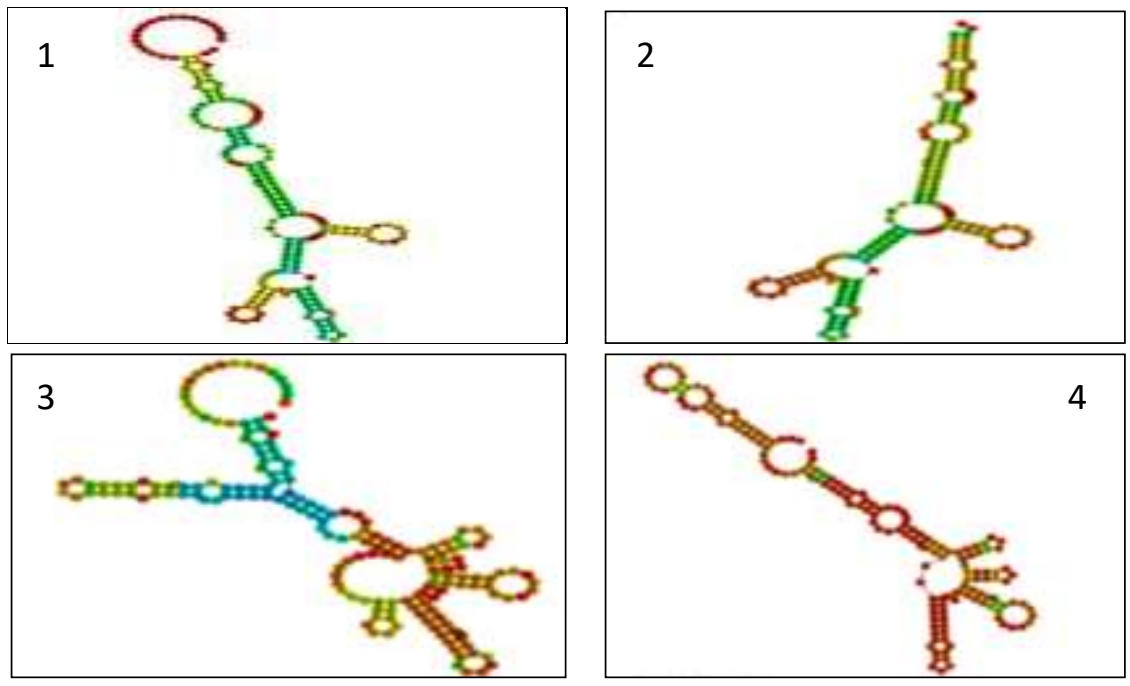

Plate (3) The determind secondry structure of RNA in normal adult(1), patient1(2), normal pediatric (3),patient 1(4).

Table (4) The mRNA and predicted protein for adult samples.

\begin{tabular}{|c|c|c|}
\hline Samples & Mrna & Protein \\
\hline $\begin{array}{l}\text { Tlx1 adult } \\
\text { control }\end{array}$ & $\begin{array}{l}\text { Ggg ggu ucu ucuucu ucg geg cgu gca gga agu gug } \\
\text { cgg acg ucu aga cge ucg acc ucu ucg cga agg ugg cgg } \\
\text { ucu uca ugg acc gga gcc ggc ucg cgc ggc ggg acc } \\
\text { ggu ucc geg agu uuu acu ggc uac geg ucc agu uuu } \\
\text { gga cca agg ucu ugg ceg ccu guu uca ccu cca cuc guu }\end{array}$ & $\begin{array}{l}\text { Gly gly ser ser ser ser ala arg ala gly ser val arg } \\
\text { thr ser arg arg ser thr ser ser arg arg trp arg ser } \\
\text { ser trp thr gly ala gly ser arg gly gly thr gly ser } \\
\text { ala ser phe thr gly tyr ala ser ser phe gly pro arg } \\
\text { ser trp pro pro val ser pro pro leu val }\end{array}$ \\
\hline $\begin{array}{l}\text { Tlx1 adult } \\
\text { patient } 1\end{array}$ & $\begin{array}{l}\text { Aa gug ugg cgg gac guc uag acg cuc gac cuc uuc geg } \\
\text { aag gug gcg guc uuc aug gac cgg agc cgg cuc geg } \\
\text { cgg cgg gac cgg uuc cge gag uuu uac ugg cua cgc } \\
\text { guc cag uuu ugg acc aag guc uug gcc gec ugu uuc } \\
\text { acc ucc acu cgu }\end{array}$ & $\begin{array}{l}\text { A ser val ala gly arg leu asp ala arg pro leu arg } \\
\text { glu gly glygly leu his gly pro glu pro ala arg ala } \\
\text { ala gly pro val pro arg val leu leu ala thr arg pro } \\
\text { val leu asp gln gly leu gly arg leu phe his leu his } \\
\text { ser u }\end{array}$ \\
\hline $\begin{array}{l}\text { Tlx1 adult } \\
\text { patient } 2\end{array}$ & $\begin{array}{l}\text { Gga ggg ucu ucu ucu ucg gcg cgu gca gga agu gug } \\
\text { cgg acg ucu aga cge ucg acc ucu ucg cga agg ugg cgg } \\
\text { uuu uca ugg acc gga gec ggc ucg cgc ggc ggg acc } \\
\text { ggu ucc geg agu uuu acu ggc uac geg ucc agu uuu } \\
\text { gga cca agg ucu ugg ceg ccu guu uca ccu cca cuc gu }\end{array}$ & $\begin{array}{l}\text { Gly gly ser ser ser ser ala arg ala gly ser val arg } \\
\text { thr ser arg arg ser thr ser ser arg arg trp arg phe } \\
\text { ser trp thr gly ala gly ser arg gly gly thr gly ser } \\
\text { ala ser phe thr gly tyr ala ser ser phe gly pro arg } \\
\text { ser trp pro pro val ser pro pro leu gu }\end{array}$ \\
\hline
\end{tabular}

Table (5) The mRNA and predicted protein for pediatric samples.

\begin{tabular}{|c|c|c|}
\hline Samples & Mrna & Protein \\
\hline $\begin{array}{l}\text { Tlx1 } \\
\text { children } \\
\text { control }\end{array}$ & $\begin{array}{l}\text { Gg ggu ucu ucu ucu ucg gcg cgu gca gga agu gug cgg acg } \\
\text { ucu aga cgc ucg acc ucu ucg cga agg ugg cgg ucu uca ugg } \\
\text { acc gga gcc ggc ucg cge ggc ggg acc ggu ucc gcg agu uuu } \\
\text { acu ggc uac geg ucc agu uuu gga cca agg ucu ugg ccg ccu } \\
\text { guu uca ccu cca cuc guu }\end{array}$ & $\begin{array}{l}\text { G gly phe phe phe phe gly ala cys arg lys } \\
\text { cys ala asp val stop thr leu asp leu phe ala } \\
\text { lys val ala val phe met asp arg ser arg leu } \\
\text { ala arg arg asp arg phe arg glu phe tyr trp } \\
\text { leu arg val gln phe trp thr lys val leu ala ala } \\
\text { cys phe thr ser thr arg u }\end{array}$ \\
\hline $\begin{array}{l}\text { Tlx1 } \\
\text { children } \\
\text { patient } 1\end{array}$ & $\begin{array}{l}\text { Uu ugg cgc ggg cgg aaa gug cgg gag ucu gaa cgc ucg cac } \\
\text { cuc uuc gcg aag ugg cgg ucu uca gga ccg ggg ccg gcu cgc } \\
\text { gcg gcg gga acc ggu ucc gcg agu uuu acu ggc uac gcg ucc } \\
\text { auu uug gaa cca agu cuu ggc cgc cug uuu cac cuc cac ucg } \\
\text { uu }\end{array}$ & $\begin{array}{l}\text { U leu ala arg ala glu ser ala gly val stop thr } \\
\text { leu ala pro leu arg glu val ala val phe arg thr } \\
\text { gly ala gly ser arg gly gly asn arg phe arg } \\
\text { glu phe tyr trp leu arg val his phe gly thr lys } \\
\text { ser trp pro pro val ser pro pro leu val }\end{array}$ \\
\hline $\begin{array}{l}\text { Tlx1 } \\
\text { pediatric } \\
\text { patient } 2\end{array}$ & $\begin{array}{l}\text { Ucu ucg ggg ggg cag gaa gug gcg gac guu aga cgc ucg acc } \\
\text { ucu ucg cgg aug ggu cgg ccu uca ugg acc gga gcc ggc ucg } \\
\text { cgc ggc ggg acc ggu ucc gcg agu uuu acu ggc uac geg ucc } \\
\text { agu uuu gga cca agg ucu ugc cac uuu uca ccu cca cu }\end{array}$ & $\begin{array}{l}\text { Ser ser gly gly gln glu val ala asp val arg } \\
\text { arg ser thr ser ser arg met gly arg pro ser trp } \\
\text { thr gly ala gly ser arg gly gly thr gly ser ala } \\
\text { ser phe thr gly tyr ala ser ser phe gly pro arg } \\
\text { ser cys his phe ser pro pro cu }\end{array}$ \\
\hline
\end{tabular}

From the analysis of the obtained above sequence the physico-chemical properties of each possible protein product in relation to each gene and each case were analyzed and determined by Expasy software. For the ease of comparison, the collected data were listed in tables (6) and (7). 
Table (6) The physico-chemical properties of possible protein of TLX1 gene in adult patient samples.

\begin{tabular}{|c|c|c|c|c|c|}
\hline TLX1 gene & category & Name of properties & Control & Sample 1 & Sample 2 \\
\hline \multirow{11}{*}{ 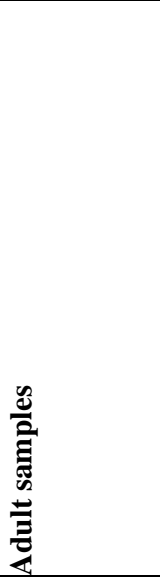 } & \multirow{5}{*}{ 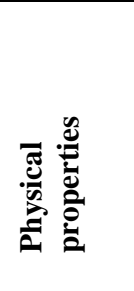 } & $\begin{array}{l}\text { Number of negatively } \\
\text { charges }\end{array}$ & 4 & 4 & 4 \\
\hline & & $\begin{array}{l}\text { Number of positively } \\
\text { charges }\end{array}$ & 17 & 12 & 17 \\
\hline & & Total number of atoms & 1011 & 1017 & 1027 \\
\hline & & Theoritical PI* & 11.11 & 10.67 & 11.34 \\
\hline & & Molecular weight & 7020.29 & 6030 & 71.66 \\
\hline & $\stackrel{\mathscr{E}}{=}$ & Number of amino acids & $\begin{array}{l}58 \text { ( Acidic :4, Basic } \\
: 18, \text { Polar : } 14 \text {, non- } \\
\text { polar :22) }\end{array}$ & $\begin{array}{l}50 \text { ( Acidic : } 4 \text {, Basic } \\
: 14 \text {, Polar : } 12 \text {, non- } \\
\text { polar :20) }\end{array}$ & $\begin{array}{l}59 \text { ( Acidic : } 4 \text {, Basic } \\
: 18 \text {,Polar : } 16 \text {, non- } \\
\text { polar :21) }\end{array}$ \\
\hline & 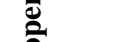 & Aliphatic index & 57.41 & 35.80 & 56.44 \\
\hline & $\overline{2}$ & Half life time & $>20$ hours & 3.5 hours & 1.9 hours \\
\hline & त & Instability index & 30.49 & 35.80 & 33.85 \\
\hline & $\cdot \ddot{\Xi}$ & Formula & C315H516N98O80S2 & C268H433N85O70S2 & $\begin{array}{l}\text { C318H522N102O83S } \\
2\end{array}$ \\
\hline & ปี & GRAVY** & -1.095 & -0.858 & -1.132 \\
\hline
\end{tabular}

*PI is short name of isoelectrical point

** GRAVY is short name of grand average of hydropathy

Table (7) The physico-chemical properties of possible protein of TLX1 gene in pediatric patient samples.

\begin{tabular}{|c|c|c|c|c|c|}
\hline TLX1 gene & category & Name of properties & Control & Sample 1 & Sample 2 \\
\hline \multirow{12}{*}{ 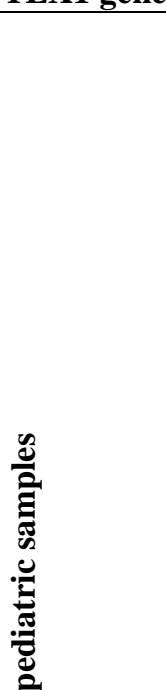 } & \multirow{5}{*}{ 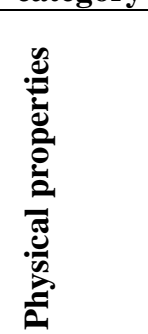 } & $\begin{array}{l}\text { Number of negatively } \\
\text { charged }\end{array}$ & 4 & 4 & 5 \\
\hline & & $\begin{array}{l}\text { Number of positively } \\
\text { charged }\end{array}$ & 17 & 11 & 12 \\
\hline & & $\begin{array}{l}\text { Total number of } \\
\text { atoms }\end{array}$ & 1011 & 848 & 869 \\
\hline & & theoritical PI* & 11.11 & 11.55 & 10.22 \\
\hline & & Molecular weight & 7020 & 6010.84 & 60.65 \\
\hline & $\stackrel{\mathscr{E}}{=}$ & $\begin{array}{l}\text { Number of amino } \\
\text { acids }\end{array}$ & $\begin{array}{l}58 \text { ( Acidic }: 4, \text { Basic } \\
: 18 \text {, Polar }: 14 \text {, non- } \\
\text { polar :22) }\end{array}$ & $\begin{array}{l}54 \text { ( Acidic :4, } \\
\text { Basic : } 11 \text {, Polar :12, } \\
\text { non-polar :24) }\end{array}$ & $\begin{array}{l}53 \text { ( Acidic }: 5 \\
\text { Basic : } 12, \text { Polar } \\
: 10, \text { non-polar :22) }\end{array}$ \\
\hline & 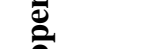 & Aliphatic index & 57.41 & 54.44 & 64.72 \\
\hline & $\stackrel{2}{2}$ & Half-life time & $>20 \mathrm{hr}$ & 1.3 hours & 1.3 hours \\
\hline & $\underline{z}$ & Instability index & 30.49 & 61.11 & 45.42 \\
\hline & 窇 & Formula & C315H516N98O80S & C261H424N88O71 & $\mathrm{C} 272 \mathrm{H} 442 \mathrm{~N} 80 \mathrm{O} 73$ \\
\hline & $\Xi$ & & 2 & & \\
\hline & & GRAVY*** & -1.095 & -1.011 & -0.858 \\
\hline
\end{tabular}

*PI is short name of isoelectrical point

** GRAVY is short name of grand average of hydropathy

\section{Discussion}

The genes TLX 1 and TLX 3 were selected as two genes of the Hox genes family in this analysis. Such genes have been shown to have a certain function in malignancies, including acute lymphoblastic $\mathrm{T}$ cell leukaemia (T-ALL). [18] Some Hox gene trials of malignancy and paediatric patients have been conducted. In the first steps of the analysis, the primers were selected based on the common way to use the GenBank method. According to the research schedule, samples obtained were analysed in the same way as each sample reached the series.
After both typical individuals approved the GenBank series, the case sequence was verified. Increased and decreased similarities were the differences. Other investigators identified this discrepancy. [22] In this review, there were several variations in the expression of these genes, not just between children but also adult and regular cases. With several other forms of tests such as the bone marrow and blood cell cytogenetic trials, immunophenotyping and PCR in real time, the possible usage of these genes as a predictor for the detection of reduced residual disease has been shown. [23] Because the differences in gene sequencing were not major, a study was carried out to find out about the 
structure and configuration of the protein product, and as it was large, physical and chemical properties had to be examined and it indicates that the protein is stable in the control adult sample with the TLX1 gene as its stability index is lower than 40 and the protein product is i.

Such research may resolve any unexplained causes for misrepresentation. The findings presented contribute to the need for further research by further patients of their cancer symptoms and their therapy responses.

This knowledge was not only related to the elevated expression of such a gene (used in patients as a disease detector), but was also found in patients with relapses. On the opposite, a rapid reduction in expression levels was observed in patients without recurrence. [17]

Further analysis on the potential protein product may be carried out and associated with cell surface markers that could be essential to improve the therapy potential. Further trials are still needed to confirm these clinical findings.

\section{References}

[1] O.A Bernard, M.Busson-LeConiat, P.Ballerini, M.Mauchauffé, V.Della Valle, R.Monni, F.N. Khac, T.Mercher, V.Penard-Lacronique, P.Pasturaud, L.Gressin, R.Heilig, M.T,Daniel, M. Lessard, R.Berger. (Introduction to cancer biology ).vol.1 ,pp.1-48,2001.

[2] M. Hejmadi. Introduction to cancer biology. BoonBooks.com.vol.8,pp.77-88,2010.

[3] American Cabncer Society, About Childhood Leukemia.vol1,pp.800.227.2345, 1ancer.org 111,2018

[4] M.Roy, A.Mukherjee, S.Mukherjee. ( Phytochemicals as an Adjuvant in Leukemia Therapy. Leukemia Causes, Symptoms \& Treatment,).vol.8,pp.1-14,2017.

[5] K.De Keersmaecker, and A.Ferrando. ( TLX1induced T-cell acute lymphoblastic leukemia. Clinical Cancer Research).vol. 17,pp.1-7,2011.

[6] A.A Ferrando, D.S.Neuberg, J.Staunton, M.L Loh, C.Huard, S.C.Raimondi, F.G.Behm, C.H Pui, J.R.Downing, D.G.Gilliland, E.S.Lander, T.R.Golub, A.T.Look.(Gene expression signatures define novel oncogenic pathways in $\mathrm{T}$ cell acute lymphoblastic leukemia. Cancer Cell):chapter.vol.1,pp. 75-87, 2002.

[7] P.W.H.Holland, H.A.F.Booth, E.A.Bruford, (Classification and nomenclature of all human homeobox genes. BMC Biology ).vol.5,pp. 129,2007.

[8] M.Tontonoz.(Immune System Cancer The Vital Connection Cancer And The Immune System: The Vital Connection).vol.2,pp.1-10,2016.
[9] K.De Keersmaecker, and A,Ferrando. ( TLX1induced T-cell acute lymphoblastic leukemia. Clinical Cancer Research).vol.17,pp.1-7,2011.

[10] P.Van Vlierberghe, I.Homminga, L.Zuurbier, J.Gladdines-Buijs, E.R.van Wering, M .Horstmann, H.B.Beverloo, R.Pieters, J. P. P. Meijerink 2008).( Cooperative genetic defects in TLX3 rearranged pediatric T-ALL. Leukemia).vol.22,pp.1-9 ,2008.

[11] C.Lenz, H.Dihazi. (Introduction to proteomics technologies. In Methods in Molecular Biology).vol.1362,pp. 3-27,2016.

[12] P.Svoboda, A.Di Cara. Hairpin RNA: A secondary structure of primary importance. Cellular and Molecular Life Sciences.vol. 63,pp.(7-8),2006.

[13] Scitable , Glossary-Definition Gel Electrophoresis. Nature Education.vol.8,pp.1$6,2014$.

[14] EDVOTEK, Inc,(principles and Practice of Agarose Gel Electrophoresis).vol.4,pp.1-26,2013.

[15] S.Atawodi, J.Atawodi, A.Dzikwi. (Polymerase chain reaction: Theory, practice and application: A review. Sahel Medical Journal).vol.13,pp.211,2011 .

[16] S.Karlin, L.RCardon. (Computational DNA Sequence Analysis. Annual Review of Microbiology) .vol.48(1),pp.619-654,1994.

[17] E.P Noronha, F.G Andrade, C.Zampier, C.F.C.Gde Andrade, E.Terra-Granado, Pombo-deOliveira,2016.

[18] P.Myers. Hox genes in development: The Hox code. Nature Education.vol. 1(1),pp.2-9, 2008.

[19] A.L.Leukemia, T.Factor, Y.Sac, E.Region, T.Hoang. T Cell Acute Lymphocytic Leukemia Protein 1 Adult and Fetal Stem Cells,2017.

[20] R.van de Schoot, S. Depaoli, R.King. Bayesian statistics and modelling. Nat Rev Methods Primers.vol.1,pp.1,2021.

[21] Immunophenotyping with CD135 and CD117 predicts the FLT3, IL-7R and TLX3 gene mutations in childhood T-cell acute leukemia. Blood Cells, Molecules, and Diseases.vol. 57,pp. 74-80,2018.

[22] P.Ballerini, A.Blaise, M.Busson-Le Coniat, X..Y. u, J.Zucman-Rossi, M.Adam, J.Van Den Akker. HOX11L2 expression defines a clinical subtype of pediatric T-ALL associated with poor prognosis. Blood.vol.100(3),pp. 991-997. https://doi.org/10.1182/blood-2001-11-0093,2002.

[23] N.Genbank, NR.Sequence, F.Go, L.Nm, D.Homo, A.Nm, V.Nm, K.Refseq, S.,Homo, O,Homo. Immunophenotyping, T., Blood, J., Mol, C., Res, A. Homo sapiens Tacell leukemia homeobox 3 (TLX3), mRNA.vol. 3,pp. 6-8,2017. 